\title{
THE IMPACT OF COMPETENCY AND PROFESSIONALISM ON AUDIT QUALITY
}

\author{
Dedy Sudarmadi \\ Langlangbuana University, Indonesia \\ dedy.trowulan@gmail.com
}

\begin{abstract}
Audit quality is a service that is difficult to measure objectively and is a complex and difficult concept to understand, so that there may be errors in determining its nature and quality. In an audit examination, the auditor must frequently interact or interact with management, this is done to obtain the evidence required in the audit examination. The attitude of the auditor is to recognize the need for an objective assessment of the conditions under investigation and the evidence obtained during the audit. This is done by the auditor so that the audited company's financial statements can be relied on and management will also get confidence and trust from outside parties that management has carried out its responsibilities properly.
\end{abstract}

Keywords: Competence, Professionalism, and Audit Quality

\section{INTRODUCTION}

Audit is a process in the assessment and evaluation of an organization, company, or institution so that it generates opinions or from third parties regarding complete, relevant, fair and accurate financial reports according to the professional standards of public accountants by taking into account the standards of the public accountant's code of ethics. Evaluation of organizations, companies or institutions results in opinions from third parties on financial reports that are accurate, complete, relevant, fair and in accordance with applicable accounting principles and regulations. Audit has a function as a process to reduce misalignment of information contained between managers and shareholders by using external parties to provide endorsement of the financial statements. Users of financial statements, especially shareholders, will make decisions based on the reports prepared by the auditors. This means that auditors have an important role in ratifying a company's financial statements. Therefore, the auditor must produce a quality audit so as to reduce the inconsistencies between management and owners. Internal Audit
So it can be concluded that Internal Audit is an examination carried out by the company's internal audit section, on the company's financial statements and accounting records as well as adherence to top management policies to test and evaluate organizational activities carried out. So it can be concluded that the quality of Internal Audit is an examination carried out by the company's internal audit department, on the company's financial statements and accounting records as well as adherence to top management policies regarding the accuracy of information reported by the auditor in accordance with audit standards to test and evaluate organizational activities carried out. Internal Audit Function that are carried out regularly can prevent a problem from occurring, management will be able to immediately identify and resolve the problem and its causes before the problem becomes sustainable, or correctly identify the real problem, the sources of the cause and take effective steps to resolve it. . (Hery, 2018: 2). Internal auditors must carry out examinations objectively. Objective is the independent mental attitude that internal auditors must have in carrying out an 
JASa (Jurnal Akuntansi, Audit dan Sistem Informasi Akuntansi)

Vol. 4 No. 3/ December 2020

ISSN 2550-0732 print / ISSN 2655-8319 online

examination. In conducting internal examinations, internal auditors may not judge something based on the results of other people's assessments. An objective attitude will allow internal auditors to have absolute confidence in the results of their work and will not make judgments of consensual or questionable quality. Internal auditors must be able to free themselves from a situation that can make them unable to provide professional and objective assessments. (Hery, 2013: 59-60). So it can be concluded that audit quality is the accuracy of an auditor in delivering information that has been adjusted to the audit standards in a financial report where errors or irregularities occur. Audit Quality results of the audit examination are in accordance with the quality of the audit so that it can be trusted by interested parties. In measuring audit quality as the basis for the auditor's opinion, the audit standard requires the auditor to obtain reasonable assurance that the financial statements as a whole are free from material misstatement, caused by fraud or error. A viable guarantee is a guarantee at a high level. Reasonable assurance is achieved when the auditor obtains sufficient appropriate audit evidence to reduce audit risk (that is, the risk that the auditor may give an incorrect opinion when financial statements are materially misstated) to an acceptably low level. However, reasonable assurance is not an absolute level of assurance, because there are inherent constraints in an audit that cause most of the audit evidence (on which the auditor's conclusions and opinions are based) is persuasive and not conclusive. According to (Demartini and Truccco, 2017: 38) Audit quality can be defined as the auditor's expertise in finding weaknesses in the client company's accounting system and reporting it. Audit quality is how likely it is for an auditor to find an unintetional error from the company's financial statements, and how likely it is that the findings will then be reported and included in the audit opinion (Junaidi and Nurdiono, 2016: 9). Furthermore, audit quality is the probability that the financial statements contain material errors and the auditors will find these material errors (Junaidi, and Nurdiono, 2016: 8) Meanwhile, according to T. Mathius, (2016: 80$)$ Audit quality is the probability of an auditor in determining and reporting an error or fraud that occurs in a client's accounting system. Audit quality is the accuracy of information reported by the auditor in accordance with the auditing standards used by the auditor, including information on accounting violations in the financial statements of the client company (Yadianti, 2018: 113).Meanwhile, according to Winwin and Mubarok (2017: 113), "Audit quality is the accuracy of information reported by the auditor in accordance with the auditing standards used by auditors including information about accounting viola tions in the financial statements of their client companies." Meanwhile, according to Yadiati, Winwin and Abdulloh Mubarok (2017: 113): "Audit quality is the accuracy of the information reported by the auditor in accordance with the auditing standards used by auditors, including information on accounting violations in the financial statements of client companies." Another opinion according to Tandiontong, Mathius (2016: 80) Audit quality is the probability of an auditor determining and reporting an error or fraud that occurs in a client's accounting system. Based on this, it can be concluded that audit quality is the probability of the auditor finding material errors, unintentional / intentional

Submitted: December 04, 2020; Accepted: December 08, 2020; 
JASa (Jurnal Akuntansi, Audit dan Sistem Informasi Akuntansi)

Vol. 4 No. 3/ December 2020

ISSN 2550-0732 print / ISSN 2655-8319 online

errors, fraud, or violations in the accounting system or financial statements of his clients, as well as the possibility of the auditor reporting the findings. Professionalism Is a responsible attitude in making decisions on users of the audit report. Thus the auditor in making decisions must be based on professional considerations so as to carry out totality and be wise in conducting audits so as to produce quality audits. Asmara, Husna (2015: 1) Professionalism is the commitment of members of a profession to improve their professional abilities by continuously developing strategies according to their profession. According to Idi, Abdullah and Safarina (2015: 100) explain that "Professionalism is an idea that develops in line with the changes and dynamics of modern society which are increasingly complex. Therefore, making the right decisions, both for oneself and for others, is getting increasingly difficult, because it requires adequate information and data. " Based on this description, it can be concluded that professionals are devotion to the profession and belief in the profession with a high level of professionalism will result in good audit quality. Professionalism is the commitment of members of a profession which refers to attitudes, goals or qualities in order to improve their professional abilities by continuously developing strategies that will be used according to their profession. The objective of auditors' professionalism is to fulfill their responsibilities with the highest standards of professionalism in order to achieve the highest level of performance oriented towards the public interest. To achieve this goal, there are four basic needs that must be met, namely credibility, professionalism, and service quality. The auditor must be able to make decisions without any influence from other parties in accordance with the judgments made based on conditions and circumstances. To gain assurance that all services obtained from the auditor are provided with the highest performance standards, the auditor must be confident that there is a professional ethical framework that underlies the provision of services by the auditor. Competence is the ability and expertise possessed by an auditor in carrying out an audit. The auditor must be qualified to understand the criteria used and must be competent to know the type and amount of evidence to be collected in order to reach the correct conclusion after examining the evidence. Competence can be measured using knowledge and experience indicators. Knowledge is shown by the auditor's understanding of the audit, the client's business and the criteria used and the non-formal education he has attended, while experience is shown by the number of clients audited, the length of time in carrying out the audit services and the type of company being audited. used and must be competent to know the type and amount of evidence to be collected in order to reach an appropriate conclusion after examining the evidence. experience is shown by the number of clients being audited, the length of time in carrying out the audit services and the type of company being audited According to Arens et al (2014: 4) "Auditor competence is a skill that is sufficiently explicit to be used in conducting audits objectively as measured from experience and knowledge of facts and procedures. Then Tandiontong Mathius (2016: 288) suggests that "competence can be measured using indicators of knowledge and experience." Knowledge is shown by the auditor's understanding of audits, 
JASa (Jurnal Akuntansi, Audit dan Sistem Informasi Akuntansi)

Vol. 4 No. 3/ December 2020

ISSN 2550-0732 print / ISSN 2655-8319 online

client efforts, and the criteria used and non-formal education that has been followed. In improving audit quality, it is necessary to increase the competence possessed in the form of knowledge or experience. Fulfilling the growing need for professional auditor services, makes the profession obliged to improve performance, this is in order to produce audit results that can be trusted by parties with an interest (Prasetyawati et al, 2018).

Based on the description, competence has two important factors, namely the knowledge and skills of procedural dayng shown in the audit experience, so competence has an influence on the quality of audits with sufficient and explicit knowledge and experience to be able to audit objectively.

\section{Research purposes}

According to Sugiyono (2018: 2) The research method is basically a scientific way to get data with specific purposes and uses. Based on this, there are four key words that need to be considered, namely, scientific method, data, purpose, and usability. Research is a scientific way to obtain valid data with the aim of being able to find, prove, develop certain knowledge so that in turn it can be used to understand, solve, and anticipate problems. The purpose of doing research is to broaden knowledge and obtain information.

\section{METHODS}

The object of research at the Public Accounting Firm in West Java. The source of information in this study can use two types of data:

Primary Data, 2. Secondary Data

\section{Research design}

Descriptive research: research that is used to analyze data by describing or describing the data that has been collected and aims to obtain a description or description of the research variables consisting of Competence (X1), Professionalism (X2), Audit Quality (Y).

\section{Population Determination}

According to Sujarweni V. Wiratna (2015: 80) population, namely the entire number consists of objects or subjects that have certain characteristics and qualities that are determined by researchers to be examined and then drawn conclusions. The research sample was 39 respondents at the Public Accounting Firm in West Java. According to Sugiyono (2018: 126) validity testing is done by correlating the total score. Furthermore, Sugiyono (2018: 121) a valid instrument, namely to obtain data, the measuring instrument used must be valid. Valid means what should be measured then the instrument can be used to measure. According to Sugiyono (2018: 183) the validity formula using the product moment correlation technique:

$$
\mathbf{r}=\frac{n \sum x 1 y 1-\left(\sum X\right)\left(\sum Y\right)}{\sqrt{\left\{n \sum x 1^{2}-\left(\sum X 1\right)^{2}\right\}\left\{n \sum Y 1^{2}-\left(\sum Y\right)^{2}\right\}}}
$$

Where:

$\mathrm{n}=$ Number of observations/ respondents.

$X=$ Score of question / statement items

$Y=$ total score of questions / statements

$r=$ the coefficient of the validity of the question / statement being sought

The next step is to determine the t-value with the formula: 


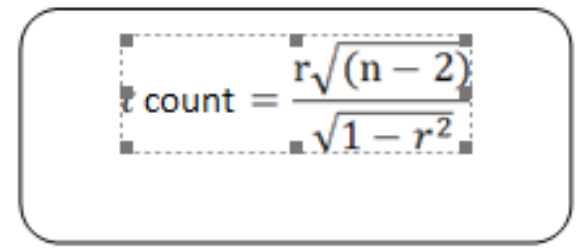

Uji Reliabilitas

Externally, the reliability of measuring instruments can be tested by analyzing the consistency of items on the instrument with certain techniques. In the study, an internal reliability analysis was used using the Alpha Chronbach approach (Sujarweni, V. Wiratna, 2015: $110)$, with the following formula:

$$
r_{11}=\left(\frac{k}{k-1}\right)\left(\frac{\sum \sigma_{b}^{2}}{\sum t^{2}}\right)
$$

Where:

$=$ Instrument reliability value

$\mathrm{k}=$ Number of questions / statements

$\mathrm{Y}=$ total score of questions / statements

$=$ The number of grain variances

$=$ Total Variance

According to Sugiyono (2018: 184) to find out whether the data tested for reliability is very strong, strong, medium, low and very low, it can be determined from: $0.0-0.199=$ indicates very low reliability $0.2-0.399=$ indicates low reliability $0.4-0.599=$ indicates moderate reliability $0.6-0.799=$ indicates strong reliability $0.8-1,000=$ shows very strong reliability

\section{Validity test}

The validity test is carried out to ascertain how well an instrument is used to measure the concept that should be measured. According to Sugiyono (2018: 183) the formula for validity using the correlation technique:

$$
t_{\text {hitung }}=\frac{\mathrm{r} \sqrt{(\mathrm{n}-2)}}{\sqrt{1-r^{2}}}
$$

Where:

$\mathrm{n}=$ Number of observations/ respondents.

$X=$ Score of question / statement items

$Y=$ total score of questions / statements

$r=$ the coefficient of the validity of the question / statement being sought Analysis of the Correlation Coefficient and the Coefficient of Determination

Siregar (2017: 251) reveals that there are several statistical techniques that can be used in analyzing the relationship between several variables, namely:

\section{Correlation Coefficient}

The correlation coefficient is a number that states the strength of the relationship between two or more variables or can also determine the direction of the two variables. Correlation value $(r)=(-1 \leq 0 \leq 1)$. For the strength of the relationship, the value of the correlation coefficient is between -1 and 1 , while the direction is expressed in the form of positive (+) and negative (-). For example: If $r=-1$ means a perfect negative correlation, meaning that there is an opposite relationship between variable $X$ and variable $Y$, if variable $X$ increases, then variable $Y$ decreases. If $r$ $=1$ means perfect positive correlation, meaning that there is a direct relationship between variable $X$ and variable $Y$, if variable $X$ increases, then variable $Y$ increases.

\section{RESULTS AND DISCUSSION}

The decision criterion is that certain questions / statements are said to

Submitted: December 04, 2020; Accepted: December 08, 2020; 
JASa (Jurnal Akuntansi, Audit dan Sistem Informasi Akuntansi)

Vol. 4 No. 3/ December 2020

ISSN 2550-0732 print / ISSN 2655-8319 online

be valid if the t-count value $\geq \mathrm{t}$-table at $\alpha$ $=5 \%$. Conversely, if the $\mathrm{t}$-count value $<\mathrm{t}-$ table, then the question / statement item is invalid, and must be corrected / replaced by another question / statement.

Guidelines for decisions in validity test research are as follows: If $r$ count $>r$ table, then the questionnaire item is declared valid. If $r$ count $<r$ table, then the questionnaire item is declared invalid

Table 1. Variable Validity Test X1 (Competency)

\begin{tabular}{cccc}
\hline Item & rcount & rtable & Decision \\
\hline 1. & 0,367 & 0,316 & Valid \\
2. & 0,652 & 0,316 & Valid \\
3. & 0,502 & 0,316 & Valid \\
4. & 0,579 & 0,316 & Valid \\
5. & 0,617 & 0,316 & Valid \\
6. & 0,488 & 0,316 & Valid \\
7. & 0,595 & 0,316 & Valid \\
8. & 0,686 & 0,316 & Valid \\
9. & 0,449 & 0,316 & Valid \\
10. & 0,540 & 0,316 & Valid \\
\hline
\end{tabular}

Source: SPSS Data Processing version 25.0 (2020)

The results of testing the validity of the questionnaire items indicate that the overall statement items for each variable $\mathrm{X} 1$ (Competence) have a correlation value above 0.316 so that

Table 2. Uji Validitas Variabel X2 (Profesionalisme)

\begin{tabular}{cccc}
\hline Item & rcount & rtable & Decision \\
\hline 1. & 0,679 & 0,316 & Valid \\
2. & 0,641 & 0,316 & Valid \\
3. & 0,760 & 0,316 & Valid \\
4. & 0,686 & 0,316 & Valid \\
5. & 0,713 & 0,316 & Valid \\
6. & 0,492 & 0,316 & Valid \\
7. & 0,605 & 0,316 & Valid \\
8. & 0,528 & 0,316 & Valid \\
9. & 0,591 & 0,316 & Valid \\
10. & 0,467 & 0,316 & Valid \\
11. & 0,538 & 0,316 & Valid \\
12. & 0,496 & 0,316 & Valid \\
13. & 0,577 & 0,316 & Valid \\
14. & 0,616 & 0,316 & Valid \\
15. & 0,641 & 0,316 & Valid \\
16. & 0,469 & 0,316 & Valid \\
17. & 0,720 & 0,316 & Valid \\
\hline
\end{tabular}

they are declared valid as reliable evidence that the questionnaire items can be accepted and further processed as the variables under study. 
JASa (Jurnal Akuntansi, Audit dan Sistem Informasi Akuntansi)

Vol. 4 No. 3/ December 2020

ISSN 2550-0732 print / ISSN 2655-8319 online

Source: SPSS Data Processing version 25.0 (2020)

The results of testing the validity of the questionnaire items indicate that the overall statement items for each variable X2 (professionalism) have a correlation value above 0.316 so that it is declared valid as reliable evidence that the questionnaire items can be accepted and further processed as the variables under study.

Table 3. Uji Validitas Variabel Y (Kualitas Audit)

\begin{tabular}{cccc}
\hline Item & rcount & rtable & Decision \\
\hline 1. & 0,598 & 0,316 & Valid \\
2. & 0,677 & 0,316 & Valid \\
3. & 0,703 & 0,316 & Valid \\
4. & 0,663 & 0,316 & Valid \\
5. & 0,709 & 0,316 & Valid \\
6. & 0,594 & 0,316 & Valid \\
7. & 0,583 & 0,316 & Valid \\
8. & 0,641 & 0,316 & Valid \\
\hline
\end{tabular}

Source: SPSS Data Processing version 25.0 (2020)

The results of testing the validity of the questionnaire items indicate that the overall statement items for each variable $Y$ (Audit Quality) have a correlation value above 0.316 so that they are declared valid as reliable evidence that the questionnaire items can be accepted and further processed as the variables under study.

\section{Data Reliability Test}

The reliability test is an index value that will show the extent to which the results of the research conducted can be measured. So it can be said that the reliability test is described to test statements that were previously valid and test the constraints in order to know the extent to which the results of the measurements remain consistent if the measurements are repeated against similar symptoms. Cronbach's Alpha> 0.60 is said to be reliable. The reliability test was carried out using the SPSS version 25.0 program with 39 respondents who obtained the following results:

Table 4. Variable Reliability Test X1 (Competency)

$$
\text { Reliability Statistics }
$$

Cronbach's N of Items

Alpha

0,762

10

Source: SPSS Data Processing version 25.0 (2020)
Submitted: December 04, 2020; Accepted: December 08, 2020;

Published: December 16, 2020; Website: http://journalfeb.unla.ac.id/index.php/jasa 
Based on the data above, the independence variable obtained Cronbach's Alpha of 0.764 , so the questionnaire on this variable is said to be reliable because it is $>$ than 0.60 .

Table 5 . X2 Variable Reliability Test (Professionalism)

\section{Reliability Statistics}

Cronbach's N of Items

\begin{tabular}{cc} 
Alpha & \\
\hline 0,890 & 17
\end{tabular}

Source: SPSS Data Processing version 25.0 (2020)

Based on the data above, the internal auditor professional skepticism variable obtained Cronbach's Alpha of
0.890 , so the questionnaire on this variable is said to be reliable because it is $>0.60$.

Table 6. Variable Reliability Test Y (Quality Audit)

$\begin{aligned} & \text { Reliability Statistics } \\ & \text { Cronbach's Alpha } \quad \text { N of Items }\end{aligned}$
$\begin{aligned} & 0,801 \\ & \text { Source: SPSS Data Processing version } 25.0(2020)\end{aligned}$

Based on the data above, the audit quality detection variable obtained Cronbach's Alpha of 0.801 , so the questionnaire on this variable was said to be reliable because it was $>0.60$.

\section{Discussion}

Competence towards audit quality shows the relationship between the two by obtaining a value of 0.436 or $43.60 \%$, namely the correlation value is positively related. This is influenced by the auditors who have the ability and expertise to carry out audits. The results of hypothesis testing state that competence has an effect on audit quality. Professionalism towards audit quality shows that the relationship between the two is 0.499 or $49.9 \%$, where the correlation value is positively related.
This is influenced by the auditor who has knowledge, experience and is responsible.

\section{CONCLUSION}

Competence has a positive impact on audit quality and, this is influenced by auditors who have expertise in carrying out audits, while auditor professionalism has an impact on audit quality which is influenced by audit factors maintaining good relationships with fellow professional associates and mutually maintaining the good name of the profession in carrying out internal audits. The competency and professionalism variables together have an effect on audit quality. This shows that

Submitted: December 04, 2020; Accepted: December 08, 2020; 
the ups and downs of audit quality are influenced by the level of competence and professionalism of the auditors. The contribution of competence and professionalism has a significant effect on audit quality. This indicates that the abilities and skills that are supported by the auditor's experience are the basis needed by an auditor in the audit process.

\section{REFERENCES}

Arens, Alvin, A., Elder, Randal, J., \& Mark, S Beasley. (2014). Jasa Audit \& Assurance

Asmara, H. 2015. Profesi Kependidikan. Bandung: Alfabeta.

Audit (Studi Kasus pada Kantor Akuntan Publik di Kota Bandung).

Demartini Chiara \& Sara $\mathrm{T} S$. 2017. Integrated Reporting and Audit Quality: AnEmpirical Erlangga. Jakarta.

Hery 2018. Modern Internal Auditing. Jakarta. PT. Grasindo.

Idi, A. d. 2015. Etika Pendidikan. Jakarta: Raja Grafindo Persada.

Junaidi, d. N. 2016. Perspektif Opini Going Concern. Yogyakarta: Andi Offset.

Junaidi, Nurdianto, 2016. Kualitas Audit; perspektif opini going conrern. Penerbit CV Andi Offset (penerbit andi). Yogyakarta.

Sukarmanto, E. (2019). Pengaruh Fee Audit dan Audit Tenur terhadap Kualitas Audit (Studi Kasus pada Kantor Akuntan

Nurhsanah, R. 2018. "Pengaruh Akuntabilitas dan Profesionalisme Auditor Terhadap Kualitas Audit Internal". Jurnal Ekonomi.
Oktaroza, M. L., \& Sukarmanto, E. (2019). Pengaruh Fee Audit dan

Audit Tenur terhadap Kualitas

Publik di Kota Bandung). Prosding Akuntansi, 5(1), 62-67.

Sugiyono. 2018. Metode Penelitian Kuantitatif, Kualitatif dan R\&D. Bandung: Alfabeta.

Tandiontong, M. 2016. Kualitas Audit dan Pengukurannya. Bandung: Alfabeta.

Wijayanto, P. A. 2017. "Pengaruh Kompetensi Independensi Profesionalisme Auditor Internal Pemerintah Terhadap Kualitas Audit". Jurnal Profita.

Yadiati Winwin \& Mubarok Abdulloh. 2018. Kualitas Pelaporan Keuangan. Jakarta: Kencana Latifhah, S.

Yadiati, W. d. 2017. Kualitas Pelaporan Keuangan Kajian Teoretis dan Empiris. Jakarta: Kencana.

Submitted: December 04, 2020; Accepted: December 08, 2020; 